\title{
Relationship of glycaemic index with cardiovascular risk factors: analysis of the National Diet and Nutrition Survey for people aged 65 and older
}

\author{
Joanne E Milton ${ }^{1}$, Blandine Briche ${ }^{2}$, lan J Brown ${ }^{3}$, Mary Hickson ${ }^{1}$, Claire E Robertson 3,4 \\ and Gary S Frost ${ }^{5, *}$ \\ ${ }^{1}$ Nutrition and Dietetic Research Group, Hammersmith Hospital, Du Cane Road, London W12 OHS, UK: ${ }^{2}$ Institut \\ National Agronomique Paris-Grignon, 16 rue Claude Bernard, F-75231 Paris, France: ${ }^{3}$ Department of \\ Epidemiology \& Public Health, Imperial College London, St Mary's Campus, Norfolk Place, London W2 IPG, UK: \\ ${ }^{4}$ Department of Human and Health Sciences, School of Biosciences, University of Westminster, Cavendish Campus, \\ $115 \mathrm{New}$ Cavendish Street, London WIW 6UW, UK: ${ }^{5}$ School of Biomedical and Molecular Sciences, University of \\ Surrey, Guilford, Surrey, GU2 7XH, UK
}

Submitted 26 September 2006: Accepted 17 January 2007: First published online 24 April 2007

\begin{abstract}
Objective: To identify associations between dietary glycaemic index (GI) and weight, body mass index and other risk factors for cardiovascular disease (CVD) - waist-tohip ratio (WHR), lipoprotein fractions, triacylglycerols (TAG) and blood pressure (BP) - in an older British population.

Design: Cross-sectional dietary, anthropometric and biochemical data from the National Diet and Nutritional Survey for adults aged over 65 years were reanalysed using a hierarchical regression model. Associations between body weight, CVD risk factors, and dietary factors including GI and fibre intakes were explored among 1152 healthy older people living in the UK between 1994 and 1995.

Results: In the unadjusted model, GI was significantly and directly associated with TAG $(\beta=0.008 \pm 0.003)$ and diastolic BP $(\beta=0.325 \pm 0.164)$ in males. These relationships were attenuated and non-significant after adjustment for potential confounding factors. WHR $(\beta=0.003 \pm 0.001)$ and TAG $(\beta=0.005 \pm 0.002)$ were significantly predicted by GI in males and females combined. The association with WHR was attenuated by adjustment for sex, age, region and social class; the relationship with TAG was non-significant after adjustment for other potential dietary confounders.

Conclusion: After controlling for potential confounders, no clear links were detected between GI and body weight or other CVD risk factors. This study provides little evidence for advising the consumption of a low-GI diet in the elderly to prevent weight gain or improve other CVD risk factors.
\end{abstract}

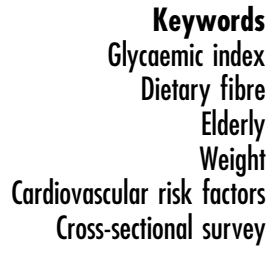

The 2003 World Health Report attributes 29.2\% of global deaths to cardiovascular disease $(\mathrm{CVD})^{1}$. Overall, CVD is estimated to cost the UK close to $£ 26$ billion per year: $56 \%$ from direct health-care costs, 24\% from reduced productivity and $16 \%$ as a result of informal care ${ }^{2}$. Advancing age is the principal non-modifiable risk factor for this disease $^{3}$ and, given that the UK population is ageing ${ }^{4}$, research efforts must focus on primary prevention to tackle the growing public health burden. High blood pressure (BP), smoking and high total cholesterol (TC) levels are the principal modifiable risk factors for CVD mortality ${ }^{5}$, although risk is not limited to these factors.

A wealth of evidence is available describing the CVD risk attributable to adiposity (estimated, for example, using body mass index (BMI; $\left.\mathrm{kg} \mathrm{m}^{-2}\right)^{6}$ or waist-to-hip ratio $\left.(\mathrm{WHR})^{7}\right)$; serum TC, low-density lipoprotein cholesterol (LDL-C) ${ }^{8}$ and high-density lipoprotein cholesterol (HDL-C) ${ }^{9}$; serum triacylglycerols (TAG) ${ }^{10}$; and dietary fats $^{11,12}$. Less is known about the potential role of dietary carbohydrate $^{13}$.

The glycaemic index (GI) ranks carbohydrate-containing foods based on the increase in blood glucose following their consumption relative to that following consumption of an equi-carbohydrate portion of a reference food (white bread or glucose) ${ }^{14}$. This index is therefore more informative than measuring the quantity of carbohydrate consumed alone. The exaggerated glucose and insulin responses that occur when consuming a highGI diet could increase the risk of CVD via a number of mechanisms. These include oxidative stress as a result of 
postprandial hyperglycaemia and independent effects of hyperinsulinaemia on lipid profile, blood pressure, coagulation factors, inflammatory mediators and endothelial function ${ }^{15}$.

Table $1^{16-29}$ summarises previous research investigating the relationship between GI and CVD risk factors. Two publications have reviewed the efficacy of low-GI diets for weight loss; however their conclusions differ, highlighting the controversy surrounding low-GI diets. Raben ${ }^{18}$ concluded that there was no evidence to support the use of low-GI diets for long-term weight control. Of the 20 longer-term studies reviewed (duration ranging from 6 days to 6 months) mean weight loss was $1.5 \mathrm{~kg}$ on the lowGI diets compared with $1.6 \mathrm{~kg}$ (not significant, NS) on the high-GI diets. When including only the nine studies that were well-controlled for energy, macronutrient and fibre intake, the mean weight loss was greater on the low-GI diets $(-3.0 \pm 1.8$ vs. $-2.8 \pm 1.1 \mathrm{~kg}$, NS). This latter finding echoes those reported by Brand-Miller et al. ${ }^{9}$. Four medium-term (duration range 5-18 weeks) human intervention studies were examined, with two demonstrating greater weight or fat loss on low- vs. high-GI diets and two showing no significant difference. Findings from animal models that support a beneficial role of low-GI diets for weight loss were also included. For example, rats fed a diet based on high-GI starch, but otherwise matched for energy and macronutrient intakes, had increased visceral fat stores and reduced rates of lipolysis ${ }^{30}$. BrandMiller et $a l .{ }^{19}$ suggested that animal studies provide mechanistic evidence and contradict the assumption that all calories are equal in terms of effect on weight gain. Suggestive evidence is available from well-controlled, sufficiently powered studies to suggest that decreased dietary GI is associated with a reduced risk from CVD; however, as reasoned in both review articles, longer-term randomised controlled trials (RCTs) are necessary to elucidate this relationship in different population groups and to investigate the effects of conventional energyrestricted vs. ad libitum low-GI diets on weight loss for example.

A $10 \%$ reduction in LDL-C $(P<0.05)^{21}$, elevations in HDL-C $\left(0.08-0.25 \mathrm{mmol}^{-1}\right.$ greater in the lowest quintile, $P<0.05)^{23,26}$ and reductions in TAG $(-37.2$ vs. $-19.1 \%$, $P=0.005)^{22}$ have been observed with low- vs. high-GI diets. Two meta-analyses (of 15 and 16 RCTs, respectively) examining the effects of low-GI diets on blood lipid levels found evidence for a beneficial effect of low-GI diets on TC and limited evidence for a reduction in LDL-C in subjects with type 2 diabetes. No benefit was observed for either HDL-C or TAG ${ }^{16,17}$. However, many of the studies reviewed were methodologically flawed, under-powered or of short duration.

No standard definitions exist to quantify 'low'- and 'high'-GI diets, although a difference of at least 10-15 units is observed in most publications ${ }^{17}$. Between-study differences in these definitions may contribute to the inconsistent results of clinical trials to date. Many low-GI foods (e.g. granary bread, pasta, beans and pulses) are high in fibre and inadequate control for differences in fibre intake - a potentially cardioprotective factor ${ }^{31,32}$ - may confound studies of dietary GI and cardiovascular health $^{33}$. The glycaemic load (GL), calculated as total amount of daily carbohydrate $(\mathrm{g}) \times \mathrm{GI}$, is a measure of the overall postprandial glycaemic effect of a food or meal. High-GL diets have also been associated with an increased risk of coronary heart disease (CHD) ${ }^{24}$ and detrimental effects on CVD risk factors ${ }^{29}$. In the current study the effect of GI alone is examined. Relationships between other carbohydrate-related dietary variables (fibre, GL, carbohydrate intake) and CVD risk factors are currently being analysed for this cohort and will be the subject of future publications.

Evidence for an association between dietary GI and CVD risk in free-living settings is conflicting, and data are particularly limited in elderly populations. Here, data from the National Diet and Nutrition Survey of adults aged 65 years and over (referred to hereafter as NDNS) are examined to determine if low dietary GI is associated with lower body weight, BMI, WHR, BP and a more favourable serum cholesterol profile.

\section{Subjects and design}

The $\mathrm{NDNS}^{34}$ is a comprehensive, cross-sectional survey which collected data on dietary habits and nutritional status. All individuals who agreed to participate completed a descriptive interview detailing general eating habits, medications, socio-economic and health status before they were invited to take part in further data collection. All subsequent interviews (e.g. 4-day weighed intake record, blood and urine collections) were optional. Only data collected from free-living, non-institutionalised participants are considered here; no subjects were following a weight-loss diet at the time of the survey.

NDNS methods are reported in detail elsewhere ${ }^{34}$. Briefly, anthropometric measurements were carried out at the participant's home, with their shoes removed, wearing light clothing. Height was measured to the nearest $1 \mathrm{~mm}$ using a portable, digital telescopic stadiometer; weight to the nearest $100 \mathrm{~g}$ using Soehnle Quantratronic digital scales. BMI was calculated as weight $(\mathrm{kg})$ divided by the square of height $\left(\mathrm{m}^{2}\right)^{35}$. Duplicate waist and hip measurements were made using an insertion tape, and WHR was calculated from the mean of two readings. Three supine BP measurements were taken from the right arm at intervals of $1 \mathrm{~min}$ using an automated sphygmomanometer (DINAMAP; GE Health Systems). Blood samples were collected after an overnight fast and analysed for TC, HDL-C, LDL-C and TAG concentrations ${ }^{34}$.

Participants were issued with Soehnle Quanta digital food scales and two 4-day dietary record sheets: one for use at home and a simplified form for use outside home. 
Table 1 Summary of previous research investigating the relationship between GI and CVD risk factors

\begin{tabular}{|c|c|c|c|c|c|c|c|c|c|}
\hline Study category & Study type & $\begin{array}{l}\text { Author } \\
\text { and date }\end{array}$ & $\begin{array}{l}\text { Number of } \\
\text { subjects }\end{array}$ & $\begin{array}{c}\text { Subject } \\
\text { characteristics }\end{array}$ & $\begin{array}{l}\text { Outcome } \\
\text { measure(s) }\end{array}$ & $\begin{array}{l}\text { Intervention } \\
\text { period }\end{array}$ & $\begin{array}{l}\text { Difference in GI, } \\
\text { mean (SD) } \\
\text { or range }\end{array}$ & Results & Significance \\
\hline \multirow[t]{17}{*}{ Intervention } & \multirow[t]{6}{*}{ Meta-analysis } & \multirow[t]{6}{*}{$\begin{array}{l}\text { Opperman } \\
\quad \text { et al. }(2004)^{16}\end{array}$} & \multirow[t]{6}{*}{396} & Adults with T1DM (105) & \multirow[t]{6}{*}{$\begin{array}{l}\text { Change in fructosamine, } \\
\text { HbA1c, HDL-C, LDL-C, } \\
\text { TC and TG conc }\end{array}$} & \multirow[t]{6}{*}{$\begin{array}{l}12 \text { days to } \\
6 \text { months }\end{array}$} & 24 (9) units & $\begin{array}{l}\downarrow \text { in fructosamine in low-Gl } \\
\text { groups }\left(-0.1 \mathrm{mmoll}^{-1}\right)\end{array}$ & $P=0.05$ \\
\hline & & & & Adults with T2DM (228) & & & 21 (7) units & $\begin{array}{l}\downarrow \text { in } \mathrm{HbA} 1 \mathrm{c} \text { in low-Gl } \\
\text { groups }(-0.27 \%)\end{array}$ & $P=0.03$ \\
\hline & & & & Healthy adults (17) & & & 22 (9) units & $\begin{array}{l}\text { No difference in HDL-C conc } \\
\qquad\left(-0.03 \mathrm{mmoll}^{-1}\right)\end{array}$ & $P=0.23$ \\
\hline & & & & Adults with CHD (46) & & & 21 (10) units & $\begin{array}{l}\downarrow \text { in LDL-C conc in low-Gl } \\
\text { groups }\left(-0.15 \mathrm{mmoll}^{-1}\right)\end{array}$ & $P=0.06$ \\
\hline & & & & & & & 22 (8) units & $\begin{array}{l}\downarrow \text { in TC conc in low-Gl } \\
\text { groups }\left(-0.33 \mathrm{mmoll}^{-1}\right)\end{array}$ & $P<0.001$ \\
\hline & & & & & & & 20 (9) units & $\begin{array}{l}\text { No difference in TG conc } \\
\left(0.03 \mathrm{mmoll}^{-1}\right)\end{array}$ & $P=0.73$ \\
\hline & \multirow[t]{6}{*}{ Meta-analysis } & \multirow[t]{6}{*}{$\begin{array}{l}\text { Kelly et al. } \\
(2004)^{17}\end{array}$} & \multirow[t]{6}{*}{325} & $\begin{array}{l}\text { Adults with at least } \\
1 \text { major risk factor for } \\
\text { CHD or diagnosed } \\
\text { with } \mathrm{CHD}\end{array}$ & \multirow[t]{6}{*}{$\begin{array}{l}\text { Change in weight, fasting } \\
\text { glucose, fasting insulin, } \\
\text { TC, HDL-C, LDL-C, TG } \\
\text { and HbA1c conc }\end{array}$} & \multirow[t]{6}{*}{$\begin{array}{l}4 \text { weeks to } \\
6 \text { months }\end{array}$} & 5 to 32 units & $\begin{array}{l}\text { Pooled } \downarrow \text { in TC of }-0.17 \mathrm{mmoll}^{-1} \\
\text { for the low- vs. the high-Gl group }\end{array}$ & \multirow[t]{6}{*}{$P=0.03$} \\
\hline & & & & & & & & $\begin{array}{l}\text { No difference in change in HDL-C } \\
\text { between diets }\end{array}$ & \\
\hline & & & & & & & & $\begin{array}{l}\text { No difference in change } \\
\text { in LDL-C between diets }\end{array}$ & \\
\hline & & & & & & & & $\begin{array}{l}\text { No difference in change } \\
\text { in TG conc between diets }\end{array}$ & \\
\hline & & & & & & & & $\begin{array}{l}\text { No difference in change } \\
\text { in body weight between diets }\end{array}$ & \\
\hline & & & & & & & & $\begin{array}{l}\text { No difference in change in fasting } \\
\text { glucose, fasting insulin or } \\
\text { HbA1c between diets }\end{array}$ & \\
\hline & $\begin{array}{l}\text { Review - medium- } \\
\text { term human studies }\end{array}$ & Raben $(2002)^{18}$ & 538 & $\begin{array}{l}\text { Normal weight, overweight } \\
\text { or obese children and adults }\end{array}$ & Change in weight & $\begin{array}{l}6 \text { days to } \\
6 \text { month }\end{array}$ & Not provided & $\begin{array}{l}\text { No difference in mean weight loss } \\
\text { between low- and high-Gl diets } \\
(-1.5 \mathrm{~kg} \text { vs. }-1.6 \mathrm{~kg})\end{array}$ & $P>0.05$ \\
\hline & \multirow[t]{2}{*}{$\begin{array}{l}\text { Review - medium- } \\
\text { term human } \\
\text { studies }\end{array}$} & \multirow[t]{2}{*}{$\begin{array}{l}\text { Brand-Miller } \\
\quad \text { et al. }(2002)^{19}\end{array}$} & \multirow[t]{2}{*}{170} & \multirow[t]{2}{*}{$\begin{array}{l}\text { Overweight or } \\
\text { obese children } \\
\text { and adults }\end{array}$} & \multirow[t]{2}{*}{$\begin{array}{l}\text { Change in weight, } \\
\text { WC, fat mass }\end{array}$} & \multirow[t]{2}{*}{$\begin{array}{l}5 \text { weeks to } \\
4 \text { months }\end{array}$} & \multirow[t]{2}{*}{ Not provided } & $\begin{array}{l}3 \text { of } 4 \text { studies observed a greater } \\
\text { in weight, BMI or fat mass on } \\
\text { low- vs. high-Gl diets }\end{array}$ & $P<0.05$ \\
\hline & & & & & & & & $\begin{array}{l}1 \text { of } 4 \text { showed no difference } \\
\text { in weight loss between diets }\end{array}$ & $P>0.05$ \\
\hline & \multirow[t]{2}{*}{ Meta-analysis } & \multirow[t]{2}{*}{$\begin{array}{l}\text { Brand-Miller } \\
\quad \text { et al. }(2003)^{20}\end{array}$} & \multirow[t]{2}{*}{356} & \multirow[t]{2}{*}{ Adults with T2DM } & \multirow[t]{2}{*}{$\begin{array}{l}\text { Change in } \mathrm{HbA} 1 \mathrm{c} \text { and } \\
\text { fructosamine conc }\end{array}$} & \multirow[t]{2}{*}{$\begin{array}{l}12 \text { days to } \\
12 \text { months }\end{array}$} & \multirow[t]{2}{*}{ Not provided } & $\begin{array}{l}\text { Low-Gl diets reduced HbA1c } \\
\text { by } 0.43 \% \text { points more } \\
\text { than high-Gl diets }\end{array}$ & \multirow[t]{2}{*}{$P<0.05$} \\
\hline & & & & & & & & $\begin{array}{l}\text { Low-Gl diets reduced glycated } \\
\text { proteins (HbA1c and fructosamine) }\end{array}$ & \\
\hline
\end{tabular}




\begin{tabular}{|c|c|c|c|c|c|c|c|c|c|}
\hline Study category & Study type & $\begin{array}{l}\text { Author } \\
\text { and date }\end{array}$ & $\begin{array}{l}\text { Number of } \\
\text { subjects }\end{array}$ & $\begin{array}{l}\text { Subject } \\
\text { characteristics }\end{array}$ & $\begin{array}{l}\text { Outcome } \\
\text { measure(s) }\end{array}$ & $\begin{array}{l}\text { Intervention } \\
\text { period }\end{array}$ & $\begin{array}{l}\text { Difference in Gl, } \\
\text { mean (SD) } \\
\text { or range }\end{array}$ & Results & Significance \\
\hline & $\begin{array}{l}\text { Parallel randomised } \\
\text { study }\end{array}$ & $\begin{array}{l}\text { Sloth et al. } \\
\qquad(2004)^{21}\end{array}$ & 45 & $\begin{array}{l}\text { Healthy overweight } \\
\text { females }\end{array}$ & $\begin{array}{l}\text { Change in weight, } \\
\text { fat mass, fasting } \\
\text { insulin, insulin } \\
\text { resistance, } \beta \text { - cell } \\
\text { function, NEFA, } \\
\text { TC, HDL-C, } \\
\text { LDL-C and TG conc }\end{array}$ & 10 weeks & $\begin{array}{l}17 \text { units for } \\
\text { test foods } \\
\text { provided }\end{array}$ & $\begin{array}{l}\text { No difference in change in } \\
\text { weight or fat mass } \\
\text { between diets }\end{array}$ & $P>0.05$ \\
\hline & & & & & & & & $\begin{array}{l}\text { No difference in fasting insulin, } \\
\text { insulin resistance, } \beta \text {-cell function, } \\
\text { TG, NEFA or HDL-C conc }\end{array}$ & $P>0.05$ \\
\hline & & & & & & & & Greater $\downarrow$ in LDL-C on ow-Gl diet & $P<0.05$ \\
\hline & $\begin{array}{l}\text { Parallel } \\
\text { randomised study }\end{array}$ & $\begin{array}{l}\text { Ebbeling et al. } \\
\qquad(2005)^{22}\end{array}$ & 23 & $\begin{array}{l}\text { Healthy obese } \\
\text { young adults }\end{array}$ & $\begin{array}{l}\text { Weight, TG, PAI-1, } \\
\text { TC, insulin } \\
\text { sensitivity, BP }\end{array}$ & 12 months & $\begin{array}{l}6.6 \text { units at } \\
12 \text { months }\end{array}$ & $\begin{array}{l}\text { No difference in change in } \\
\text { weight between diets }\end{array}$ & $P>0.05$ \\
\hline & & & & & & & & $\begin{array}{l}\text { No difference in change in } \\
\text { TG, PAl-1, TC, insulin } \\
\text { sensitivity or BP }\end{array}$ & $P>0.05$ \\
\hline & & & & & & & & $\begin{array}{l}\text { Greater } \downarrow \text { in TG concentration } \\
\text { in low-Gl group }(-37.2 \% \\
\text { vs. }-19.1 \%)\end{array}$ & $P=0.005$ \\
\hline & & & & & & & & $\begin{array}{l}\text { PAl-1 } \downarrow \text { in intervention group } \\
(-39.0 \%) \text { and } \uparrow \text { in the } \\
\text { conventional group (33.1\%) }\end{array}$ & $P=0.004$ \\
\hline \multirow[t]{6}{*}{ Epidemiological } & $\begin{array}{l}\text { Cross-sectional } \\
\text { study }\end{array}$ & $\begin{array}{l}\text { Frost et al. } \\
\qquad(1999)^{23}\end{array}$ & 1420 & Healthy adults & $\begin{array}{l}\text { TC, HDL-C and } \\
\text { LDL-C conc }\end{array}$ & $\mathrm{N} / \mathrm{A}$ & $N / A$ & $\begin{array}{l}\text { Inverse relationship between } \\
\text { Gl and HDL-C }\end{array}$ & $\begin{array}{c}P=0.02 \text { for males } \\
P<0.0001 \text { for } \\
\text { females }\end{array}$ \\
\hline & & & & & & & & $\begin{array}{l}\text { No significant relationship between } \\
\text { Gl and TC or LDL-C }\end{array}$ & \\
\hline & $\begin{array}{l}\text { Prospective } \\
\text { study, 10-year } \\
\text { follow-up period }\end{array}$ & $\begin{array}{l}\text { Liu et al. } \\
\qquad(2000)^{24}\end{array}$ & 75521 & $\begin{array}{l}\text { Healthy } \\
\text { adult females }\end{array}$ & CHD incidence & $\mathrm{N} / \mathrm{A}$ & $\mathrm{N} / \mathrm{A}$ & $\begin{array}{l}\text { Direct relationship between } \\
\text { GL and CHD risk }\end{array}$ & $\begin{array}{c}P<0.0001 \text { for } \\
\text { linear trend }\end{array}$ \\
\hline & $\begin{array}{l}\text { Prospective study, } \\
\text { 10-year follow-up } \\
\text { period and cross- } \\
\text { sectional study }\end{array}$ & $\begin{array}{l}\text { van Dam } \\
\quad \text { et al. }(2000)^{25}\end{array}$ & $\begin{array}{l}646 \\
\quad \text { (prospective); } \\
394 \text { (cross- } \\
\text { sectional) }\end{array}$ & Elderly males & $\begin{array}{l}\text { CHD incidence; } \\
\text { metabolic risk } \\
\text { factors }\end{array}$ & $\mathrm{N} / \mathrm{A}$ & $\mathrm{N} / \mathrm{A}$ & $\begin{array}{l}\text { No relationship between } \\
\text { Gl and CHD risk }\end{array}$ & $\begin{array}{l}P=0.70 \text { for } \\
\text { linear trend }\end{array}$ \\
\hline & & & & & & & & $\begin{array}{l}\text { No relationship between } \\
\text { Gl and TC, HDL-C, TG, } \\
\text { (fasting or post-load) } \\
\text { glucose or insulin conc }\end{array}$ & \\
\hline & $\begin{array}{l}\text { Cross-sectional } \\
\text { study }\end{array}$ & $\begin{array}{l}\text { Ford \& Liu } \\
\qquad(2001)^{26}\end{array}$ & 13907 & Healthy adults & HDL-C conc & $N / A$ & $N / A$ & $\begin{array}{l}\text { Inverse relationship between } \\
\text { Gl/GL and HDL-C } \\
15 \text {-unit } \uparrow \text { in Gl associated } \\
\text { with a } \downarrow \text { in } \mathrm{HDL}-\mathrm{C} \text { of } \\
0.06 \mathrm{mmol}^{-1}\end{array}$ & $\begin{array}{r}P<0.001 \text { for } \\
\text { linear trend }\end{array}$ \\
\hline
\end{tabular}


Table 1. Continued

\begin{tabular}{|c|c|c|c|c|c|c|c|c|c|}
\hline Study category & Study type & $\begin{array}{l}\text { Author } \\
\text { and date }\end{array}$ & $\begin{array}{l}\text { Number of } \\
\text { subjects }\end{array}$ & $\begin{array}{c}\text { Subject } \\
\text { characteristics }\end{array}$ & $\begin{array}{l}\text { Outcome } \\
\text { measure(s) }\end{array}$ & $\begin{array}{l}\text { Intervention } \\
\text { period }\end{array}$ & $\begin{array}{c}\text { Difference in Gl, } \\
\text { mean (SD) } \\
\text { or range }\end{array}$ & Results & Significance \\
\hline & $\begin{array}{l}\text { 1-year longitudinal } \\
\text { analysis }\end{array}$ & $\begin{array}{l}\text { Ma et al. } \\
(2005)^{47}\end{array}$ & 572 & $\begin{array}{l}\text { Healthy } \\
\text { adults }\end{array}$ & Change in BMI & $\mathrm{N} / \mathrm{A}$ & $\mathrm{N} / \mathrm{A}$ & $\begin{array}{l}\text { Direct relationship between } \\
\text { Gl and BMI } \\
5 \text {-unit } \uparrow \text { in } \mathrm{Gl} \text { associated } \\
\text { with } \uparrow \text { of } 0.75 \mathrm{BMI} \text { units } \\
\text { from cross-sectional } \\
\text { data and } \uparrow \text { of } 0.04 \text { units } \\
\text { from longitudinal data }\end{array}$ & $\begin{array}{c}\text { Cross-sectional: } \\
\quad P=0.01 \\
\text { Longitudinal: } \\
P=0.02\end{array}$ \\
\hline & $\begin{array}{l}\text { Cross-sectional } \\
\text { study }\end{array}$ & $\begin{array}{l}\text { Liese et al. } \\
\quad(2005)^{28}\end{array}$ & 979 & $\begin{array}{l}\text { Healthy adults } \\
(66 \%), \text { IGT } \\
\text { adults (33\%) }\end{array}$ & $\begin{array}{l}\text { Insulin sensitivity, } \\
\text { fasting insulin, } \\
\text { acute insulin } \\
\text { response, disposition } \\
\text { index, BMI and WC }\end{array}$ & $\mathrm{N} / \mathrm{A}$ & N/A & $\begin{array}{l}\text { No relationship between Gl } \\
\text { and any outcome variable }\end{array}$ & $P>0.05$ \\
\hline & $\begin{array}{l}\text { Cross-sectional } \\
\text { study }\end{array}$ & $\begin{array}{l}\text { Slyper et al. } \\
(2005)^{29}\end{array}$ & 32 & $\begin{array}{l}\text { Healthy subjects } \\
\text { aged } 11-25 \\
\text { years }\end{array}$ & $\begin{array}{l}\text { TC, HDL-C } \\
\text { and LDL-C }\end{array}$ & N/A & N/A & $\begin{array}{l}\text { Inverse relationship between } \\
\text { GL and HDL-C }\end{array}$ & $P<0.05$ \\
\hline
\end{tabular}

GI - glycaemic index; CVD - cardiovascular disease; SD - standard deviation; T1DM - type 1 diabetes mellitus; T2DM - type 2 diabetes mellitus; CHD - coronary heart disease; IGT - impaired glucose tolerance; ence; NEFA - non-esterified fatty acids; PAI-1 - plensity lipoprotein cholesterol; LDL-C - low-density lipoprotein cholesterol; TC - total cholesterol; TG - triglycerides; conc - concentration(s); WC - wais 
A description/brand of all food and drink consumed at home was recorded alongside the weight of food served and any leftovers. For food consumed away from home where weighing was inconvenient - participants recorded a description, price and place of purchase. Trained interviewers then purchased and weighed the items. The feasibility study revealed significant differences in nutrient intake between different days of the week, so a diary placement pattern (i.e. completing a set number or proportion of diaries on each day of the week) was used in the final survey to ensure that, for example, weekday vs. weekend variation in intakes was accounted for ${ }^{36}$. Details from both diaries were matched to nutrient composition information ( 55 nutrients) using a nutrient databank of over 3500 foods, compiled by the Ministry of Agriculture, Fisheries and Foods ${ }^{37}$.

\section{GI calculation}

A GI value (reference food $=$ glucose) was added to the NDNS database for each of the 2323 carbohydratecontaining food codes recorded in the diet diaries. Values were obtained from the international table of GI and GL values ${ }^{38}$ and other published sources ${ }^{39,40}$, using means of multiple entries when available. Where no published data were available, published analogues were used (for example, the mean GI value for 'oranges' was imputed for 'clementines') or GI values were calculated from recipes using the mixed-meal formula ${ }^{41}$ : less than $1.2 \times$ BMR, considered incompatible with energy balance $^{44}$, was used here to define low energy reporters (LERs). In the feasibility study, a 24-hour urine sample was taken and $p$-aminobenzoic acid tablets were given to participants to check the completeness of the sample. Protein intakes were validated by comparing urinary and dietary nitrogen $(\mathrm{N})$ concentration: ratios of urinary $\mathrm{N}$ / dietary $\mathrm{N}$ were 0.92 for males and 0.87 for females, close to the permitted range for validity $(0.70-0.90)^{36}$.

\section{Statistical analysis}

To control for the potentially confounding effect of energy intake, all nutrient data are presented as energy-adjusted variables. HDL-C, TC/HDL-C ratio, TAG and Englyst fibre intake were log-transformed to normalise the distributions. The ratio of polyunsaturated to saturated fatty acid intake (P/S) was calculated and used in subsequent analyses to improve the stability of the regression model. Differences in means between LERs and non-LERs and between males and females were compared with unpaired $t$-tests for continuous variables and by $\chi^{2}$ tests for categorical variables.

To inform regression analyses and identify potential collinearity, a Spearman correlation matrix, controlled for energy intake (males and females separately and combined), was constructed for nutrient and physical activity level (PAL) data.

Associations of GI with CVD risk factors (weight, $n=993$; BMI, $n=983$; WHR, $n=993$; BP, $n=960$; lipoprotein sub-fractions, $n=784$; TAG, $n=1100$ ) were

$$
\mathrm{GI}_{\text {food }}=\sum_{\text {ingredient }} \frac{\mathrm{GI}_{\text {ingredient }} \times \text { Quantity of carbohydrate in the ingredient }(\mathrm{g})}{\text { Total quantity of carbohydrate in the food }(\mathrm{g})} .
$$

To calculate the average GI of each diet, the following formula was applied ${ }^{42}$ :

$\mathrm{GI}_{\text {diet }}=\sum_{\text {food }} \frac{\mathrm{GI}_{\text {food }} \times \text { Quantity of carbohydrate in the food }(\mathrm{g})}{\text { Totalquantity of carbohydrate in the } \operatorname{diet}(\mathrm{g})}$.

Many of the foods for which GI values were estimated contributed only a small proportion of the total carbohydrate consumed by each individual. To assess the relative importance of GI values obtained from various sources, the mean percentage of an individual's total carbohydrate intake attributable to each source of GI data (international tables, other published data, estimations and calculations) was calculated.

\section{Validation of dietary intake}

Basal metabolic rate (BMR), calculated using standard regression equations based on age, sex and weight (Schofield equations) ${ }^{43}$, was compared with energy intake to identify underreporting. A habitual energy intake estimate analysed using multiple linear regression. The basic model for all dependent variables was adjusted for age, region and social class (non-manual or manual, classified by main occupation prior to retirement). Analyses were carried out separately for males and females and combined (with adjustment for sex in combined analysis).

Evidence-based confounding factors were added sequentially in additional models for each dependent variable (e.g. BMI when $\mathrm{BP}$ was the dependent) ${ }^{45}$. In subsequent models, reported potential confounders were also added (e.g. P/S ratio when BP was the dependent) ${ }^{46}$. To determine if the amount of fibre consumed affected the relationship of dietary GI to the dependent variables, an interaction term (GI $\times$ Englyst fibre) was included in additional regression models.

All analyses were performed with SPSS (version 12.0; SPSS Inc.). Analyses were carried out on the full sample and repeated with the exclusion of LERs. $P$-values $<0.05$ (two-tailed) were considered statistically significant. 


\section{Results}

\section{Study population}

Of the free-living sample ( $n=2172$ individuals), 75\% ( $n=1632$ ) provided a full or partial interview (responding sample) and $78 \%(n=1275)$ of the responding sample also provided a 4-day weighed dietary intake record. Data collected from those who reported being unwell during the dietary recording period, with appetite/eating patterns affected ( $8 \%$ males, $n=50 ; 11 \%$ females, $n=73$ ), were excluded. This resulted in a maximum study population of 1152 individuals (53\% of the initial sample), of which $50.5 \%$ were male (age $75.9 \pm 7.0$ years, BMI $26.3 \pm 3.6 \mathrm{~kg} \mathrm{~m}^{-2}$; mean \pm standard deviation, SD) and $49.5 \%$ were female (age $77.6 \pm 8.0$ years, BMI $26.6 \pm 4.8 \mathrm{~kg} \mathrm{~m}^{-2}$; mean $\left.\pm \mathrm{SD}\right)$. Selected demographic, lifestyle, anthropometric, biochemical and nutrient characteristics are presented by sex in Table 2. Some $49.2 \%$ ( $n=478$ ) of individuals (39.7\% males, 59.4\% females; $P<0.001)$ were defined as LERs. The exclusion of these participants did not materially affect the outcomes, and thus only the analyses performed on the full dataset are presented.

\section{Source of GI values}

GI values were assigned to 2323 individual food codes, contributing $73 \%$ of the total weight of carbohydrate consumed by participants. Of these, 235 (10\%) were assigned a mean value from multiple entries in the international tables, and 358 (15\%) were obtained from a single entry in the international tables ${ }^{38}$. Values for 1580 (68\%) codes were estimated from analogous foods with published GI values, while 96 (4\%) were calculated by the mixed-meal method ${ }^{42}$. The 54 remaining GI values were sourced from other published data ${ }^{39,40}$. On average, GI values assigned from a mean value from the international tables contributed $43.5 \pm 14.2 \%$ (mean $\pm \mathrm{SD}$ ) of an individual's total carbohydrate intake; values obtained from a single entry $24.7 \pm 13.0 \%$; analogues $26.3 \pm 11.7 \%$; and mixed-meal calculated GI values $1.8 \pm 3.3 \%$. The remaining GI values, obtained from other published sources $^{39,40}$, contributed on average $3.5 \pm 3.4 \%$ of total carbohydrate intake.

\section{Correlation analyses}

Correlation matrices for males and females are presented in Tables 3 and 4, respectively. Dietary GI did not correlate significantly with weight, BMI, WHR, BP or any lipoprotein fraction in either sex. Dietary GI was inversely associated with Englyst fibre intakes in males and females $(r=-0.34$ and $r=-0.32$, respectively).

\section{Regression analyses}

Associations of dietary GI with weight, BMI, WHR and other CVD risk factors, with and without control for potential confounders, are reported for males and females in Tables 5 and 6, respectively.

In males, prior to controlling for potential confounders, dietary GI was directly associated with $10 \mathrm{~g}$ TAG concentration $(\beta=0.008 \pm 0.003)$. There was also a direct relationship between GI and diastolic BP $(\beta=0.325 \pm 0.164)$. However, after adjusting for age, social class and region (Model 2), neither association was statistically significant. In females, dietary GI was not significantly associated with any of the anthropometric variables or CVD risk factors assessed, either before or after adjustment for confounders.

When the analyses were repeated in males and females combined (data not shown), WHR was significantly predicted by dietary GI $(\beta=0.003 \pm 0.001 ; P<0.001)$ in Model 1. However, after controlling for sex, age, social class and region, the relationship was no longer significant. Subsequent models further reduced the strength of the relationship. Dietary GI predicted (log) TAG concentration $(\beta=0.005 \pm 0.002 ; P=0.017)$; the association remained significant after control for sex, age, social class and region (Model 2), and PAL and BMI (Model 3) $(\beta=0.004 \pm 0.002 ; P=0.049)$. Adjusting for alcohol (units week ${ }^{-1}$ ) (Model 4), carbohydrate $\left(\mathrm{g} \mathrm{day}^{-1}\right.$ ) (Model $5)$ and Englyst fibre $\left(\mathrm{g} \mathrm{day}^{-1}\right)$ (Model 6) weakened the association $(\beta=0.02 \pm 0.02 ; P=0.362)$, which became non-significant.

When the interactions between fibre and GI were considered, it was apparent that in females the nonsignificant relationships between dietary GI and weight and between dietary GI and BMI were dependent on fibre intake. The addition of a GI $\times$ fibre interaction term to the regression model revealed significant inverse associations between GI and weight $(\beta=-0.995 \pm 0.360 ; P=0.008)$ and GI and BMI $(\beta=-0.302 \pm 0.145 ; \quad P=0.038)$. Significant and borderline-significant interactions were detected between fibre and GI in males for HDL-C, TC/HDL-C ratio and TAG, indicating that the observed relationships (non-significant) of dietary GI and these outcome measures are also dependent on fibre intake.

\section{Discussion}

Carbohydrate is absorbed rapidly from high-GI (relative to low-GI) foods, causing higher postprandial glucose and insulin responses ${ }^{47}$. This encourages carbohydrate rather than fat oxidation, stimulates lipolysis and increases visceral non-esterified fatty acid release in the late postprandial period, promoting body fat gain. Low-GI carbohydrates have been associated with greater satiety and hence reductions in subsequent energy intake ${ }^{48}$. Thus, we hypothesised that low-GI diets would be associated with lower body weight, BMI, WHR, BP and a more favourable cholesterol profile in a free-living population. Our study found a high-GI diet to be associated with higher TAG concentrations and higher 
Table 2 Demographic, lifestyle, anthropometric, biochemical and dietary intake data by sex for all participants (all significant differences are highlighted)

\begin{tabular}{|c|c|c|}
\hline & Males & Females \\
\hline \multicolumn{3}{|l|}{ Demographics } \\
\hline \multicolumn{3}{|l|}{ Region } \\
\hline Scotland and Northern & 34.4 & 34.9 \\
\hline Central and South West & 42.1 & 37.5 \\
\hline London and South East & 23.5 & 27.5 \\
\hline \multicolumn{3}{|l|}{ Social class } \\
\hline Non-manual & 45.1 & 46.6 \\
\hline Manual & 54.9 & 53.4 \\
\hline Age (years) & $75.9 \pm 7.0^{*}$ & $77.6 \pm 8.0$ \\
\hline \multicolumn{3}{|l|}{ Lifestyle } \\
\hline \multicolumn{3}{|l|}{ Smoking status } \\
\hline Non (never \& ex) & 82.9 & 87.5 \\
\hline$<20$ cigarettes day $^{-1}$ & 11.0 & 10.2 \\
\hline$\geq 20$ cigarettes day $^{-1}$ & 6.0 & 2.3 \\
\hline \multicolumn{3}{|l|}{ Self-reported alcohol intake level } \\
\hline Non-drinker & 7.2 & 25.3 \\
\hline Ex-drinker & 10.8 & 8.2 \\
\hline Very low & 11.5 & 20.5 \\
\hline Low & 35.5 & 31.1 \\
\hline Moderate & 16.2 & 6.8 \\
\hline Fairly high & 8.3 & 4.0 \\
\hline High & 4.5 & 0.9 \\
\hline Very high & 2.6 & 0.4 \\
\hline Drinker, units unknown & 3.4 & 2.8 \\
\hline Estimated alcohol intake (units week ${ }^{-1}$ ) & $10.5 \pm 15.0^{\star *}$ & $3.0 \pm 5.0$ \\
\hline \multicolumn{3}{|l|}{ Maximum physical activity level } \\
\hline Vigorous (e.g. running or jogging) & 0.5 & 0.4 \\
\hline Moderate (e.g. cycling, keep fit, swimming, $\geq 20$ min brisk walking) & 79.7 & 85.4 \\
\hline Light (e.g. dancing, golf, yoga, $\geq 20$ min slow walking) & 18.4 & 13.5 \\
\hline Inactive & 1.4 & 0.7 \\
\hline BMR & $1521.5 \pm 157.1^{\star \star}$ & $1263.6 \pm 121.4$ \\
\hline El/BMR ratio & $1.26 \pm 0.30^{\star *}$ & $1.13 \pm 0.27$ \\
\hline \multicolumn{3}{|l|}{ Anthropometry } \\
\hline Height $(\mathrm{cm})$ & $169.0 \pm 6.9^{\star *}$ & $155.4 \pm 6.7$ \\
\hline Weight (kg) & $75.1 \pm 12.0^{\star \star}$ & $64.1 \pm 12.4$ \\
\hline $\mathrm{BMI}\left(\mathrm{kg} \mathrm{m}^{-2}\right)$ & $26.3 \pm 3.6$ & $26.6 \pm 4.8$ \\
\hline WHR & $0.93 \pm 0.06^{\star \star}$ & $0.84 \pm 0.07$ \\
\hline \multicolumn{3}{|l|}{ Blood pressure } \\
\hline Systolic (mmHg) & $150.1 \pm 21.9^{\star}$ & $154.5 \pm 23.8$ \\
\hline Diastolic (mmHg) & $79.7 \pm 12.7^{\star}$ & $76.7 \pm 13.5$ \\
\hline \multicolumn{3}{|l|}{ Biochemical } \\
\hline $\mathrm{TC}\left(\mathrm{mmoll} \mathrm{I}^{-1}\right)$ & $5.5 \pm 1.1^{\star \star}$ & $6.3 \pm 1.5$ \\
\hline TAG $\left(\mathrm{mmoll}^{-1}\right)$ & $1.6 \pm 0.9$ & $1.6 \pm 0.8$ \\
\hline HDL-C (mmoll $\left.{ }^{-1}\right)$ & $1.2 \pm 0.5^{\star \star}$ & $1.4 \pm 0.5$ \\
\hline LDL-C $\left(\mathrm{mmoll}^{-1}\right)$ & $4.3 \pm 1.2^{\star \star}$ & $4.9 \pm 1.5$ \\
\hline \multicolumn{3}{|l|}{ Dietary intake } \\
\hline Energy intake (kcal) & $1891.2 \pm 454.8^{\star \star}$ & $1415.3 \pm 338.0$ \\
\hline $\mathrm{CHO}$ (\% of food energy) & $49.1 \pm 7.0$ & $49.4 \pm 6.3$ \\
\hline Starch (\% of food energy) & $27.2 \pm 5.8$ & $27.3 \pm 5.3$ \\
\hline Sugar ( $\%$ of food energy) & $22.0 \pm 7.1$ & $22.0 \pm 6.8$ \\
\hline Englyst fibre (g per $1000 \mathrm{kcal})$ & $7.1 \pm 2.8^{\star \star}$ & $7.7 \pm 3.1$ \\
\hline Protein (\% of food energy) & $15.1 \pm 3.0^{\star \star}$ & $15.9 \pm 3.6$ \\
\hline Fat (\% of food energy) & $35.0 \pm 5.7^{\star \star}$ & $36.7 \pm 6.2$ \\
\hline SFA (\% of food energy) & $14.5 \pm 3.6^{\star *}$ & $15.8 \pm 4.1$ \\
\hline MUFA (\% of food energy) & $10.8 \pm 2.0$ & $11.0 \pm 2.1$ \\
\hline$n-3$ PUFA (\% of food energy) & $0.77 \pm 0.36^{\star}$ & $0.82 \pm 0.36$ \\
\hline$n-6$ PUFA ( $\%$ of food energy) & $4.8 \pm 2.1$ & $4.8 \pm 2.2$ \\
\hline $\mathrm{P} / \mathrm{S}$ ratio & $0.42 \pm 0.22$ & $0.40 \pm 0.24$ \\
\hline TFA ( $\%$ of food energy) & $1.5 \pm 0.5^{\star \star}$ & $1.6 \pm 0.5$ \\
\hline GI & $59.4 \pm 3.6^{\star \star}$ & $58.2 \pm 3.8$ \\
\hline
\end{tabular}

BMR - basal metabolic rate; EI - energy intake; BMI - body mass index; WHR - waist-to-hip ratio; TC - total cholesterol; TAG - triacylglycerols; HDL-C - high-density lipoprotein cholesterol; LDL-C - low-density lipoprotein cholesterol; CHO - carbohydrate; SFA - saturated fatty acids; MUFA - monounsaturated fatty acids; PUFA - polyunsaturated fatty acids; P/S ratio - polyunsaturated fat/saturated fat; TFA - trans fatty acids; GI - glycaemic index. Data are presented as \% (categorical variables) or mean \pm standard deviation (continuous variables).

Significant difference between males and females (unpaired Student's $t$-test for continuous variables, $\chi^{2}$ test for categorical variables): ${ }^{\star} P<0.05$, ** $P<0.01$. 
Table 3 Correlation matrix of nutrient variables for males controlled for energy intake (kcal)

\begin{tabular}{|c|c|c|c|c|c|c|c|c|c|c|c|c|c|c|c|}
\hline & $\mathrm{CHO}(\mathrm{g})$ & Sugar (g) & Starch $(\mathrm{g})$ & $\begin{array}{l}\text { Englyst } \\
\text { fibre }(\mathrm{g})\end{array}$ & Protein (g) & Fat (g) & SFA $(g)$ & MUFA (g) & $n-3$ PUFA (g) & $n-6$ PUFA (g) & ) $\mathrm{P} / \mathrm{S}$ ratio & TFA $(\mathrm{g})$ & Chol (mg) & $\mathrm{EtOH}$ (units week ${ }^{-1}$ ) & PAL \\
\hline $\begin{array}{l}\text { GI } \\
\text { CHO (g) } \\
\text { Sugar }(\mathrm{g}) \\
\text { Starch (g) } \\
\text { Englyst fibre (g) } \\
\text { Protein (g) } \\
\text { Fat (g) } \\
\text { SFA (g) } \\
\text { MUFA (g) } \\
n-3 \text { PUFA (g) } \\
n-6 \text { PUFA (g) } \\
\text { P/S ratio } \\
\text { TFA (g) } \\
\text { Chol (mg) } \\
\text { EtOH (units week }{ }^{-1} \text { ) }\end{array}$ & 0.01 & $\begin{array}{r}-0.16^{\star \star} \\
0.67^{\star \star}\end{array}$ & $\begin{array}{r}0.20^{\star \star} \\
0.43^{\star \star} \\
-0.38^{\star \star}\end{array}$ & $\begin{array}{c}-0.34^{\star *} \\
0.26^{\star *} \\
-0.05 \\
0.39^{\star *}\end{array}$ & $\begin{array}{c}-0.17^{\star \star} \\
-0.16^{\star \star} \\
-0.35^{\star \star} \\
0.22^{\star \star} \\
0.35^{\star \star}\end{array}$ & $\begin{array}{l}-0.04 \\
-0.45^{\star \star} \\
-0.42^{\star \star} \\
-0.05 \\
-0.15^{\star \star} \\
0.02\end{array}$ & $\begin{array}{l}-0.06 \\
-0.34^{\star \star} \\
-0.18^{\star \star} \\
-0.22^{\star \star} \\
-0.24^{\star \star} \\
-0.07 \\
0.78^{\star \star}\end{array}$ & $\begin{array}{l}-0.02 \\
-0.48^{\star \star} \\
-0.44^{\star \star} \\
-0.05 \\
-0.16^{\star \star} \\
0.06 \\
0.86^{\star \star} \\
0.53^{\star \star}\end{array}$ & $\begin{array}{c}-0.02 \\
-0.18^{\star \star} \\
-0.26^{\star \star} \\
0.08^{\star} \\
0.13^{\star \star} \\
0.27^{\star \star} \\
0.19^{\star \star} \\
-0.09^{\star} \\
0.28^{\star \star}\end{array}$ & $\begin{array}{c}0.04 \\
-0.03 \\
-0.24^{\star \star} \\
0.26^{\star \star} \\
0.19^{\star \star} \\
0.06 \\
0.24^{\star \star} \\
-0.33^{\star \star} \\
0.18^{\star \star} \\
0.16^{\star \star}\end{array}$ & $\begin{array}{c}0.07 \\
0.09^{\star} \\
-0.12^{\star \star} \\
0.27^{\star \star} \\
0.25^{\star \star} \\
0.08^{\star} \\
-0.12^{\star \star} \\
-0.63^{\star \star} \\
-0.07 \\
0.26^{\star *} \\
0.85^{\star \star}\end{array}$ & $\begin{array}{c}0.00 \\
-0.04 \\
-0.09^{\star} \\
0.06 \\
-0.17^{\star *} \\
-0.12^{\star *} \\
0.52^{\star *} \\
0.48^{\star \star} \\
0.40^{\star *} \\
-0.04 \\
-0.08^{\star} \\
-0.29^{\star *}\end{array}$ & $\begin{array}{c}0.00 \\
-0.34^{\star \star} \\
-0.20^{\star \star} \\
-0.19^{\star \star} \\
-0.18^{\star \star} \\
0.25^{\star \star} \\
0.33^{\star \star} \\
0.34^{\star \star} \\
0.33^{\star \star} \\
0.03 \\
-0.17^{\star \star} \\
-0.23^{\star \star} \\
0.15^{\star \star}\end{array}$ & $\begin{array}{l}\quad 0.06 \\
-0.46 \\
-0.19^{\star \star} \\
-0.34^{\star \star} \\
-0.17^{\star \star} \\
-0.09^{\star} \\
-0.27^{\star \star} \\
-0.21^{\star \star} \\
-0.15^{\star \star} \\
-0.02 \\
-0.14^{\star \star} \\
-0.01 \\
-0.31^{\star \star} \\
0.00\end{array}$ & $\begin{array}{l}0.04 \\
0.03 \\
0.04 \\
-0.01 \\
-0.11^{\star \star} \\
-0.06 \\
0.07 \\
0.07 \\
0.06 \\
-0.06 \\
-0.02 \\
-0.06 \\
0.03 \\
0.09^{\star} \\
-0.02\end{array}$ \\
\hline
\end{tabular}

CHO - carbohydrate; SFA - saturated fatty acids; MUFA - monounsaturated fatty acids; PUFA - polyunsaturated fatty acids; P/S ratio - polyunsaturated fat/saturated fat; TFA - trans fatty acids; Chol - cholesterol; EtOH - alcohol; PAL - physical activity level; GI - glycaemic index.

Significant correlation: ${ }^{*} P<0.05,{ }^{* *} P<0.01$.

Table 4 Correlation matrix of nutrient variables for females controlled for energy intake (kcal)

\begin{tabular}{|c|c|c|c|c|c|c|c|c|c|c|c|c|c|c|c|}
\hline & $\mathrm{CHO}(\mathrm{g})$ & Sugar (g) & $\begin{array}{l}\text { Starch } \\
\text { (g) }\end{array}$ & $\begin{array}{l}\text { Englyst } \\
\text { fibre (g) }\end{array}$ & Protein (g) & Fat (g) & SFA $(g)$ & $\begin{array}{l}\text { MUFA } \\
\text { (g) }\end{array}$ & $\begin{array}{c}n-3 \text { PUFA } \\
\text { (g) }\end{array}$ & $\begin{array}{c}n-6 \text { PUFA } \\
\text { (g) }\end{array}$ & $\mathrm{P} / \mathrm{S}$ ratio & TFA (g) & Chol (mg) & $\begin{array}{c}\text { EtOH } \\
\left(\text { units week }^{-1} \text { ) }\right.\end{array}$ & PAL \\
\hline $\mathrm{Gl}$ & -0.01 & $-0.32^{\star *}$ & $0.39^{\star *}$ & $-0.32^{\star *}$ & $-0.18^{\star *}$ & $0.11^{*}$ & 0.00 & $0.17^{\star *}$ & 0.05 & $0.10^{*}$ & $0.09^{*}$ & $0.09^{*}$ & 0.04 & -0.05 & 0.01 \\
\hline $\mathrm{CHO}(\mathrm{g})$ & & $0.67^{\star *}$ & $0.34^{\star \star}$ & $0.22^{\star \star}$ & $-0.24^{\star *}$ & $-0.77^{\star \star}$ & $-0.53^{\star \star}$ & $-0.68^{\star \star}$ & $-0.23^{\star \star}$ & $-0.16^{\star \star}$ & 0.07 & $-0.25^{\star \star}$ & $-0.52^{* *}$ & $-0.18^{\star \star}$ & 0.06 \\
\hline Sugar (g) & & & $-0.47^{\star \star}$ & 0.07 & $-0.22^{\star *}$ & $-0.51^{\star \star}$ & $-0.20^{\star \star}$ & $-0.52^{\star *}$ & $-0.25^{\star \star}$ & $-0.29^{\star \star}$ & $-0.14^{* *}$ & $-0.23^{\star *}$ & $-0.24^{\star \star}$ & -0.05 & 0.06 \\
\hline Starch (g) & & & & $0.16^{\star \star}$ & 0.00 & $-0.26^{\star \star}$ & $-0.37^{\star \star}$ & $-0.15^{\star \star}$ & 0.04 & $0.17^{\star *}$ & $0.26^{* *}$ & 0.00 & $-0.31^{\star *}$ & $-0.15^{\star \star}$ & 0.00 \\
\hline Englyst fibre (g) & & & & & $0.36^{\star *}$ & $-0.38^{\star \star}$ & $-0.35^{\star \star}$ & $-0.36^{\star \star}$ & $0.11^{*}$ & $0.09^{*}$ & $0.27^{* *}$ & $-0.28^{\star \star}$ & $-0.22^{\star *}$ & -0.03 & -0.06 \\
\hline Protein $(\mathrm{g})$ & & & & & & $-0.28^{\star \star}$ & $-0.30^{\star \star}$ & $-0.17^{\star \star}$ & $0.15^{\star *}$ & 0.04 & $0.21^{\star *}$ & $-0.32^{\star *}$ & $0.22^{\star \star}$ & 0.04 & $-0.10^{\star}$ \\
\hline Fat $(\mathrm{g})$ & & & & & & & $0.76^{\star \star}$ & $0.84^{\star \star}$ & $0.14^{\star \star}$ & $0.15^{\star \star}$ & $-0.20^{\star *}$ & $0.50^{\star \star}$ & $0.40^{\star \star}$ & $-0.16^{\star \star}$ & 0.01 \\
\hline SFA (g) & & & & & & & & $0.44^{\star \star}$ & $-0.16^{\star \star}$ & $-0.43^{\star \star}$ & $-0.68^{\star *}$ & $0.43^{\star \star}$ & $0.34^{\star \star}$ & $-0.13^{\star *}$ & 0.05 \\
\hline MUFA (g) & & & & & & & & & $0.27^{\star \star}$ & $0.17^{\star \star}$ & -0.08 & $0.42^{\star *}$ & $0.37^{\star \star}$ & $-0.11^{\star}$ & -0.03 \\
\hline$n-3$ PÚFA (g) & & & & & & & & & & $0.23^{\star \star}$ & $0.31^{\star *}$ & $-0.10^{\star}$ & $0.12^{\star}$ & 0.06 & $-0.09^{\star}$ \\
\hline$n-6$ PUFA (g) & & & & & & & & & & & $0.84^{* *}$ & $-0.15^{\star \star}$ & $-0.11^{\star}$ & -0.02 & -0.04 \\
\hline $\mathrm{P} / \mathrm{S}$ ratio & & & & & & & & & & & & $-0.31^{* *}$ & $-0.17^{\star \star}$ & 0.05 & -0.06 \\
\hline TFA $(\mathrm{g})$ & & & & & & & & & & & & & $0.12^{\star \star}$ & $-0.14^{\star *}$ & 0.03 \\
\hline Chol (mg) & & & & & & & & & & & & & & 0.00 & 0.02 \\
\hline $\mathrm{EtOH}$ (units week ${ }^{-1}$ ) & & & & & & & & & & & & & & & 0.08 \\
\hline
\end{tabular}

CHO - carbohydrate; SFA - saturated fatty acids; MUFA - monounsaturated fatty acids; PUFA - polyunsaturated fatty acids; P/S ratio - polyunsaturated fat/saturated fat; TFA - trans fatty acids; Chol - cholesterol; EtOH - alcohol; PAL - physical activity level; GI - glycaemic index.

Significant correlation: ${ }^{\star} P<0.05,{ }^{\star \star} P<0.01$. 
Table 5 Results of the linear regression analysis of GI and CVD risk factors in males

\begin{tabular}{|c|c|c|c|c|c|c|c|c|c|c|c|c|}
\hline & \multicolumn{2}{|l|}{ Model 1† } & \multicolumn{2}{|l|}{ Model $2 \ddagger$} & \multicolumn{2}{|l|}{ Model 3} & \multicolumn{2}{|l|}{ Model 4} & \multicolumn{2}{|l|}{ Model 5} & \multicolumn{2}{|l|}{ Model 6} \\
\hline & $B \pm \mathrm{SE}$ & $P$ & $B \pm \mathrm{SE}$ & $P$ & $B \pm \mathrm{SE}$ & $P$ & $B \pm \mathrm{SE}$ & $P$ & $B \pm \mathrm{SE}$ & $P$ & $B \pm \mathrm{SE}$ & $P$ \\
\hline Neight§ & $0.004 \pm 0.151$ & 0.98 & $-0.085 \pm 0.149$ & 0.57 & $-0.077 \pm 0.149$ & 0.60 & $-0.084 \pm 0.149$ & 0.58 & $-0.054 \pm 0.157$ & 0.73 & & \\
\hline BMI§ & $0.008 \pm 0.046$ & 0.86 & $-0.030 \pm 0.046$ & 0.52 & $-0.031 \pm 0.046$ & 0.51 & $-0.032 \pm 0.047$ & 0.49 & $-0.005 \pm 0.049$ & 0.92 & & \\
\hline WHRß & $0.001 \pm 0.001$ & 0.09 & $0.001 \pm 0.001$ & 0.29 & $0.001 \pm 0.001$ & 0.33 & $0.001 \pm 0.001$ & 0.31 & $0.001 \pm 0.001$ & 0.30 & & \\
\hline TCף & $-0.003 \pm 0.016$ & 0.84 & $-0.010 \pm 0.017$ & 0.55 & $-0.005 \pm 0.017$ & 0.75 & $-0.005 \pm 0.017$ & 0.75 & $0.000 \pm 0.017$ & 0.99 & $-0.008 \pm 0.017$ & 0.63 \\
\hline LDL-Cף & $0.000 \pm 0.016$ & 0.99 & $-0.008 \pm 0.017$ & 0.63 & $-0.005 \pm 0.017$ & 0.78 & $-0.005 \pm 0.017$ & 0.75 & $-0.002 \pm 0.017$ & 0.88 & $-0.009 \pm 0.018$ & 060 \\
\hline + HDL-C $\|$ & $-0.003 \pm 0.002$ & 0.21 & $-0.002 \pm 0.002$ & 0.36 & $-0.001 \pm 0.02$ & 0.52 & $-0.002 \pm 0.002$ & 0.35 & $-0.001 \pm 0.002$ & 0.49 & $-0.001 \pm 0.002$ & 0.57 \\
\hline + TC/HDL-C ratio\| & $0.002 \pm 0.002$ & 0.44 & $<0.001 \pm 0.002$ & 0.90 & $<0.001 \pm 0.002$ & 0.99 & $0.001 \pm 0.002$ & 0.81 & $<0.001 \pm 0.002$ & 0.91 & $0.001 \pm 0.002$ & 0.91 \\
\hline + TAG†† & $0.008 \pm 0.003$ & $0.02^{*}$ & $0.006 \pm 0.003$ & 0.07 & $0.005 \pm 0.003$ & 0.10 & $0.005 \pm 0.003$ & 0.12 & $0.005 \pm 0.003$ & 0.13 & $0.003 \pm 0.003$ & 0.35 \\
\hline 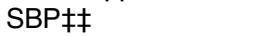 & $0.409 \pm 0.278$ & 0.14 & $0.246 \pm 0.287$ & 0.39 & $0.261 \pm 0.288$ & 0.37 & $0.219 \pm 0.288$ & 0.45 & $0.184 \pm 0.290$ & 0.52 & $0.073 \pm 0.306$ & 0.81 \\
\hline DBP $\ddagger \ddagger$ & $0.325 \pm 0.164$ & $0.05^{\star}$ & $0.164 \pm 0.167$ & 0.33 & $0.180 \pm 0.167$ & 0.28 & $0.159 \pm 0.167$ & 0.34 & $0.148 \pm 0.168$ & 0.38 & $0.026 \pm 0.177$ & 0.88 \\
\hline
\end{tabular}

GI - glycaemic index; CVD - cardiovascular disease; SE - standard error; BMI - body mass index; WHR - waist-to-hip ratio; TC - total cholesterol; LDL-C - low-density lipoprotein cholesterol; HDL-C - highdensity lipoprotein cholesterol; TAG - triacylglycerols; SBP - systolic blood pressure; DBP - diastolic blood pressure.

+ indicates dependent variables that were log-transformed to normalise before use in regression analysis.

* Significant at $P<0.05$.

† Model 1 shows unadjusted influence of GI on dependent variable.

$¥$ Model 2, for all variables, is adjusted for age, social class and region.

列

I For TC and LDL-C, Model 3 is adjusted for physical activity, energy intake and BMI; Model 4 is additionally controlled for fat intake $\left(\mathrm{g}^{-1 a y}{ }^{-1}\right)$; smoking, polyunsaturated fat/saturated fat ratio, cholesterol intake (mg day ${ }^{-1}$ ) and trans fatty acids ( $\mathrm{g}$ day ${ }^{-1}$ ) are added in Model 5 ; and Engylst fibre (g day ${ }^{-1}$ ) in Model 6.

( ally for smoking, cholesterol intake ( $\mathrm{mg}$ day $\left.{ }^{-1}\right)$ and monounsaturated fat intake $\left(\mathrm{g} \mathrm{day}^{-1}\right)$ in Model 5 and Englyst fibre $\left(\mathrm{g} \mathrm{day}^{-1}\right)$ in Model 6 .

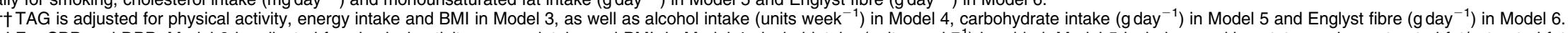

didel 5 includes smoking status, polyunsaturated fat/saturated fat ratio and

dded in Model 6. 
Table 6 Results of the linear regression analysis of GI and CVD risk factors in females

\begin{tabular}{|c|c|c|c|c|c|c|c|c|c|c|c|c|}
\hline & \multicolumn{2}{|l|}{ Model $1 \dagger$} & \multicolumn{2}{|l|}{ Model 2‡ } & \multicolumn{2}{|l|}{ Model 3} & \multicolumn{2}{|l|}{ Model 4} & \multicolumn{2}{|l|}{ Model 5} & \multicolumn{2}{|l|}{ Model 6} \\
\hline & $B \pm \mathrm{SE}$ & $P$ & $B \pm \mathrm{SE}$ & $P$ & $B \pm \mathrm{SE}$ & $P$ & $B \pm \mathrm{SE}$ & $P$ & $B \pm \mathrm{SE}$ & $P$ & $B \pm \mathrm{SE}$ & $P$ \\
\hline Weight§ & $-0.061 \pm 0.156$ & 0.70 & $-0.049 \pm 0.156$ & 0.75 & $-0.086 \pm 0.157$ & 0.58 & $-0.084 \pm 0.157$ & 0.60 & $-0.089 \pm 0.167$ & 0.60 & & \\
\hline BMı§ & $0.028 \pm 0.061$ & 0.65 & $0.020 \pm 0.063$ & 0.75 & $0.013 \pm 0.063$ & 0.84 & $0.009 \pm 0.064$ & 0.89 & $-0.005 \pm 0.068$ & 0.94 & & \\
\hline WHR§ & $0.001 \pm 0.001$ & 0.33 & $0.001 \pm 0.001$ & 0.42 & $0.001 \pm 0.001$ & 0.45 & $0.001 \pm 0.001$ & 0.46 & $0.000 \pm 0.001$ & 0.94 & & \\
\hline TCq & $0.009 \pm 0.022$ & 0.68 & $0.009 \pm 0.023$ & 0.71 & $0.009 \pm 0.023$ & 0.71 & $0.007 \pm 0.023$ & 0.76 & $0.006 \pm 0.024$ & 0.80 & $0.009 \pm 0.026$ & 0.73 \\
\hline LDL-Cף & $0.013 \pm 0.022$ & 0.56 & $0.011 \pm 0.023$ & 0.63 & $0.010 \pm 0.023$ & 0.65 & $0.009 \pm 0.023$ & 0.71 & $0.007 \pm 0.024$ & 0.78 & $0.009 \pm 0.026$ & 0.73 \\
\hline$+\mathrm{HDL}-\mathrm{C} \|$ & $<0.001 \pm 0.002$ & 0.92 & $0.001 \pm 0.002$ & 0.76 & $0.001 \pm 0.002$ & 0.68 & $0.001 \pm 0.002$ & 0.62 & $0.001 \pm 0.002$ & 0.63 & $0.002 \pm 0.002$ & 0.42 \\
\hline + TC/HDL-C ratio\| & $<0.001 \pm 0.002$ & 0.87 & $-0.001 \pm 0.002$ & 0.82 & $-0.001 \pm 0.002$ & 0.76 & $-0.001 \pm 0.003$ & 0.66 & $-0.001 \pm 0.003$ & 0.74 & $-0.001 \pm 0.003$ & 0.59 \\
\hline + TAG†† & $0.004 \pm 0.003$ & 0.10 & $0.003 \pm 0.003$ & 0.36 & $0.002 \pm 0.003$ & 0.47 & $0.002 \pm 0.003$ & 0.47 & $0.002 \pm 0.003$ & 0.47 & $0.001 \pm 0.003$ & 0.86 \\
\hline SBP $\neq \ddagger$ & $0.210 \pm 0.322$ & 0.52 & $0.110 \pm 0.329$ & 0.74 & $0.165 \pm 0.329$ & 0.62 & $0.159 \pm 0.329$ & 0.63 & $0.209 \pm 0.332$ & 0.53 & $0.159 \pm 0.361$ & 0.66 \\
\hline DBP执 & $-0.075 \pm 0.183$ & 0.68 & $-0.116 \pm 0.188$ & 0.54 & $-0.126 \pm 0.189$ & 0.51 & $-0.126 \pm 0.190$ & 0.51 & $-0.083 \pm 0.190$ & 0.66 & $-0.122 \pm 0.207$ & 0.56 \\
\hline
\end{tabular}

GI - glycaemic index; CVD - cardiovascular disease; SE - standard error; BMI - body mass index; WHR - waist-to-hip ratio; TC - total cholesterol; LDL-C - low-density lipoprotein cholesterol; HDL-C - highdensity lipoprotein cholesterol; TAG - triacylglycerols; SBP - systolic blood pressure; DBP - diastolic blood pressure.

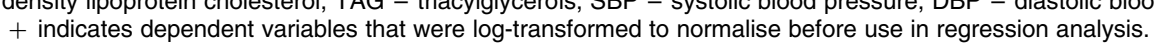

† Model 1 shows unadjusted influence of Gl on dependent variable.

$\ddagger$ Model 2 , for all variables, is adjusted for age, social class and region.

\& For weight, BMI and WHR, Model 3 is adjusted for physical activity and energy intake; fat ( $\mathrm{g} \mathrm{day}^{-1}$ ) is added to Model 4 ; and Englyst fibre $\left(\mathrm{g}_{\text {day }}{ }^{-1}\right)$ to Model 5 .

१ For TC and LDL-C, Model 3 is adjusted for physical activity, energy intake and BMI; Model 4 is additionally controlled for fat intake $\left(\mathrm{g}^{-1 a y}{ }^{-1}\right)$; smoking, polyunsaturated fat/saturated fat ratio, cholesterol intake $\left(\mathrm{mg} \mathrm{day}^{-1}\right)$ and trans fatty acids $\left(\mathrm{g} \mathrm{day}^{-1}\right)$ are added in Model 5 ; and Engylst fibre $\left(\mathrm{g} \mathrm{day}^{-1}\right)$ in Model 6 .

| HDL-C and TC/HDL-C ratio are adjusted for physical activity, energy intake and BML in Model 3; fat intake $\left(\mathrm{g}\right.$ day ${ }^{-1}$ ), polyunsaturated fat/saturated fat ratio and alcohol intake (units week ${ }^{-1}$ ) in Model 4; and additionally for smoking, cholesterol intake $\left(\mathrm{mg} \mathrm{day}^{-1}\right)$ and monounsaturated fat intake $\left(\mathrm{g} \mathrm{day}^{-1}\right)$ in Model 5 and Englyst fibre $\left(\mathrm{g} \mathrm{day}^{-1}\right)$ in Model 6.

t†TAG is adjusted for physical activity, energy intake and BMI in Model 3 , as well as alcohol intake (units week ${ }^{-1}$ ) in Model 4 , carbohydrate intake $\left(\mathrm{g}\right.$ day ${ }^{-1}$ ) in Model 5 and Englyst fibre $\left(\mathrm{g}\right.$ day ${ }^{-1}$ ) in Model 6.

fł For SBP and DBP, Model 3 is adjusted for physical activity, energy intake and BMI; in Model 4 alcohol intake (units week ${ }^{-1}$ ) is added; Model 5 includes smoking status, polyunsaturated fat/saturated fat ratio and cholesterol intake $\left(\mathrm{mg} \mathrm{day}^{-1}\right)$; and Englyst fibre $\left(\mathrm{g} \mathrm{day}^{-1}\right)$ was added in Model 6. 
diastolic BP in males. In the combined analysis of both sexes the association with TAG persisted and a direct relationship between GI and WHR was identified. These relationships were attenuated by increasing levels of adjustment for potential confounding factors, and became statistically non-significant. No significant relationships were observed for weight, BMI or lipoprotein concentrations.

Previous intervention studies investigating the efficacy of high- vs. low-GI diets for weight loss report conflicting findings ${ }^{18,19}$. Liese et al. studied 979 normal (67\%) and 'glucose tolerance impaired' (33\%) adults and found no association between GI (as assessed by food-frequency questionnaire, FFQ) and BMI or waist circumference ${ }^{28}$. This lack of association was attributed to the sample size and the exclusion of people with pre-existing CVD or diabetes, thus resulting in a cohort less susceptible to environmental exposure ${ }^{13}$. In contrast, Ma et al. found a direct association between GI (7-day dietary recall) and BMI in a longitudinal study of 572 healthy adults ${ }^{27}$. Other studies have found significant, direct relationships between GI and weight, yet these tend to include obese individuals or younger adults ${ }^{49,50}$. Fat mass increases and lean mass decreases with age, independent of body weight change. This change comprises increases in visceral adipose tissue, intramyocellular and intramuscular lipid and liver fat, and decreases in lean soft tissue and in fat-free mass ${ }^{51}$. These changes may render an elderly population less responsive to dietary changes and comparisons of studies with different population ages invalid.

Ingestion of high-GI carbohydrates results in reduced insulin sensitivity, and potentially a reduction in HDL-C and reciprocal increase in TAG concentration ${ }^{52}$. Low-GI diets improve insulin sensitivity ${ }^{53}$, therefore higher HDL-C and lower TAG concentrations might be expected in individuals following such diets. Unlike previous population studies ${ }^{23,26}$, we failed to observe an association between dietary GI and HDL-C. Our results are consistent with those from the Zutphen Elderly Study ${ }^{25}$, which examined the association between high-GI diets and hyperinsulinaemia, hyperglycaemia, dyslipidaemia and CHD risk in 394 males (64-84 years). The lack of association was attributed to the exclusion of males with a history of diabetes or myocardial infarction ${ }^{13}$; however, no such exclusions were applied here. The disparity in age may explain these differences, as TC and LDL-C levels have been shown to increase ${ }^{54}$, while fractional clearance of LDL-C $\mathrm{C}^{55}$ and the number of LDL receptors in hepatic tissue decline ${ }^{56}$, with age.

The NDNS had a low response rate $(\sim 50 \%)$, resulting in a sample size half that estimated to observe significant associations, and one potentially biased by differences in diet, lifestyle and CVD risk factors between responders and non-responders. A high proportion of LERs ( $40 \%$ males, $60 \%$ females) was identified and insufficient information is available to determine whether under- or misreporting was evident, or if reported low intakes were valid. Underreporting may not affect foods or nutrients systematically $^{57,58}$; thus, although energy adjustment controls for differences in energy intake, percentage intakes from macronutrients may remain inaccurate. Protein intake was validated in the NDNS feasibility study through comparisons of urinary with dietary nitrogen concentrations; however, no biomarkers exist for carbohydrate or fibre and therefore validation of GI calculations is not routine.

Our dietary GI values ranged from 40 to 72 units (glucose $=100$ ), with a normal distribution. In the Zutphen study ${ }^{25}$ values ranged from 39 to 65 units, with a right skewed distribution. Frost et $a l^{23}$ previously associated low-GI diets with higher HDL-C concentrations in healthy middle-aged adults. The total range of GI was not presented, however data were normally distributed and quintile means were similar to those of the current study. The lack of variation in dietary GI is unlikely to be responsible for the lack of association observed here; therefore GI calculation estimates were considered. The majority of values were obtained from international tables $^{38}$, many of which are sourced outside the UK; thus estimates for processed foods (e.g. Special K) may be invalid. Between-subject variation (for example, between diabetic and non-diabetic test groups $)^{59}$, methodological differences, and differences in preparation, processing, variety and ripeness may also introduce inaccuracies. Using the mean of multiple estimates, we attempted to improve the reliability of GI estimates, but undoubtedly inaccuracies remain that could attenuate observed associations $^{60}$.

GI values estimated from analogues contributed to approximately 26\% carbohydrate. Where recipes and mixed-meal calculations are used, effects of protein and fat from non-carbohydrate-containing foods on insulin secretion or gastric emptying are ignored ${ }^{61}$. One study of eight healthy subjects demonstrated that variations in the energy $(395-610 \mathrm{kcal})$, fat $(8-24 \mathrm{~g})$ and protein $(12-25 \mathrm{~g})$ content of a meal have little effect on the postprandial insulin and glucose response ${ }^{62}$, the amount of carbohydrate and the GI explaining 90\% of the observed variation in glucose response. Flint et al. ${ }^{41}$ disagree however. Their study of 28 subjects consuming 13 test meals found no association between the estimated GI and that obtained using in vivo GI measurements. The meals all contained $50 \mathrm{~g}$ available carbohydrate with varying amounts of fibre $(1-24 \mathrm{~g})$, fat $(3-42 \mathrm{~g})$ and protein $(5-28 \mathrm{~g})$, and hence differing energy contents $(270-715 \mathrm{kcal})^{41}$.

The current study is limited by its cross-sectional design. We are trying to detect true associations between dietary intake estimated from a 4-day record (which may or may not represent long-term habitual intake) and various CVD risk factors, which may have been influenced by diet for more than 60 years, and which are also subject to other environmental $^{63}$ and genetic ${ }^{64}$ influences. Notably, dietary 
intakes differ between adulthood and old age due to changes in physiology, dentition, and intended weight gain or loss. Problems with dentition may cause elderly individuals to eat softer, lower-fibre foods (e.g. white bread $(G I=70)$ vs. grainy/seeded bread $(G I=54)$ ) and could explain why our results do not support those of other studies; however, no food group analysis was completed here.

The physiological changes associated with ageing might limit or mask the beneficial effect of low-GI diets on body weight or CVD risk factors. The prospective Nurses' Health Study investigated the effect of GI on CVD risk ${ }^{24}$ among $>75000$ US women followed-up for 10 years. The highest quintile of GI (assessed by FFQ, relative to the lowest category) was associated with a relative risk of 1.28 $(P=0.02)$ for total CHD. We have examined risk factors for CVD independently and found no significant beneficial effect; however, small additive effects (undetectable in an epidemiological study of this size) on individual risk factors might combine to produce a measurable effect on disease incidence in the long term.

Our results provide limited evidence for a beneficial effect of low-GI diets with regard to body weight, BMI or CVD risk factors in an older British population. The relationship between GI and CVD risk may not exist in this population, or may be confounded by factors such as pre-existing CVD (58\% taking cardiovascular medications) or diabetes (15\% taking endocrine medications). Furthermore, regression analyses may be under-powered and subject to attenuation of dietary GI-CVD risk factor associations, the result of regression dilution bias introduced by unreliable dietary GI estimates $^{60}$.

No data are available on frequencies of individual or groups of foods consumed. Dairy products and high-fibre foods have low $\mathrm{GI}^{38}$, but may affect anthropometric variables, BP or dyslipidaemia differently due to variability in fibre, micronutrient, antinutrient and antioxidant levels for example. Our final regression analysis found interactions between fibre and GI in some outcome variables, indicating that a high dietary GI may be more important in low- compared with high-fibre diets. The interrelationships between GI, fibre and CVD risk warrant further research. A factorial RCT could provide key carbohydrate-containing foods and compare the CVD risk profiles of four groups following combinations of low- or high-GI and low- or high-fibre diets. Alternatively, large RCTs could be used to examine the effect of GI on anthropometric and CVD risk factors, while prospective studies assessing food intake longitudinally with anthropometric, biochemical and CVD outcomes would be informative.

This study shows some associations between dietary GI and measures of obesity, BP and lipoprotein profile in an older British population, prior to adjusting for potential confounding factors. However, there is very limited evidence in an elderly population to justify advice to lower dietary GI for CVD prevention.

\section{Acknowledgements}

Sources of funding: None.

Conflict of interest declaration: None.

Authorship responsibilities: J.E.M. was involved in formulating the hypotheses, supervising the calculation of dietary GI and undertaking the statistical analysis, and interpreting the results. B.B. was responsible for assigning GI values to foods, calculating dietary GI and preliminary statistical analysis. I.J.B. and C.E.R. provided statistical support and advice, and were responsible for manuscript editing. G.S.F. and M.H. supervised the project and were involved in all parts of the study from conception to writing of the paper. All of the investigators were involved in the writing of the paper.

Acknowledgements: The authors acknowledge the UK Data Archive (University of Essex, UK) for providing the data analysed in this study.

\section{References}

1 World Health Organization (WHO). World Health Report 2003 - Shaping the Future. Geneva: WHO, 2003.

2 British Heart Foundation. Economic Cost of CVD and CHD [online], 24 May 2005. Available at www.heartstats.org Accessed September 2005.

3 Kesteloot HE, Verbeke G. On the relationship between allcause, cardiovascular, cancer and residual mortality rates with age. European Journal of Cardiovascular Prevention and Rehabilitation 2005; 12(2): 175-81.

4 Office of National Statistics. The ageing UK population [online], 2002. Available at http://www.oheschools.org/ ohech6pg3.html. Accessed 22 September 2005.

5 Ezzati M, Lopez AD, Rodgers A, Vander HS, Murray CJ. Selected major risk factors and global and regional burden of disease. Lancet 2002; 360(9343): 1347-60.

6 Hu G, Tuomilehto J, Silventoinen K, Barengo NC, Peltonen $\mathrm{M}$, Jousilahti P. The effects of physical activity and body mass index on cardiovascular, cancer and all-cause mortality among 47212 middle-aged Finnish men and women. International Journal of Obesity 2005; 29(8): 894-902.

7 Azizi F, Esmaillzadeh A, Mirmiran P, Ainy E. Is there an independent association between waist-to-hip ratio and cardiovascular risk factors in overweight and obese women? International Journal of Cardiology 2005; 101(1): 39-46.

8 Ballantyne C, Arroll B, Shepherd J. Lipids and CVD management: towards a global consensus. European Heart Journal 2005; 26(21): 2224-31.

9 Boden WE. High-density lipoprotein cholesterol as an independent risk factor in cardiovascular disease: assessing the data from Framingham to the Veterans Affairs HighDensity Lipoprotein Intervention Trial. American Journal of Cardiology 2000; 86(12A): 19L-22L.

10 Onat A, Sari I, Yazici M, Can G, Hergenc G, Avci GS. Plasma triglycerides, an independent predictor of cardiovascular disease in men: a prospective study based on a population with prevalent metabolic syndrome. International Journal of Cardiology 2006; 108(1): 89-95.

11 Sacks FM, Katan M. Randomized clinical trials on the effects of dietary fat and carbohydrate on plasma lipoproteins and 
cardiovascular disease. American Journal of Medicine 2002; 113(Suppl. 9B): 13S-24S.

12 Ascherio A. Epidemiologic studies on dietary fats and coronary heart disease. American Journal of Medicine 2002; 113(Suppl. 9B): 9S-12S

13 Jenkins DJ, Kendall CW, Augustin LS, Vuksan V. Highcomplex carbohydrate or lente carbohydrate foods? American Journal of Medicine 2002; 113(Suppl. 9B): 30S-7S.

14 Food and Agriculture Organization of the United Nations (FAO). Carbohydrates in Human Nutrition. Report of a Joint FAO/World Health Organization Expert Consultation. FAO Food and Nutrition Paper No. 66. Rome: FAO, 1998; 1-140.

15 Ludwig DS. The glycemic index: physiological mechanisms relating to obesity, diabetes, and cardiovascular disease. JAMA: Journal of the American Medical Association 2002; 287(18): 2414-23.

16 Opperman AM, Venter CS, Oosthuizen W, Thompson RL, Vorster HH. Meta-analysis of the health effects of using the glycaemic index in meal-planning. British Journal of Nutrition 2004; 92(3): 367-81.

17 Kelly S, Frost G, Whittaker V, Summerbell C. Low glycaemic index diets for coronary heart disease. Cochrane Database of Systematic Reviews 2004; (4): CD004467.

18 Raben A. Should obese patients be counselled to follow a low-glycaemic index diet? No. Obesity Reviews 2002; 3(4): 245-56.

19 Brand-Miller JC, Holt SH, Pawlak DB, McMillan J. Glycemic index and obesity. American Journal of Clinical Nutrition 2002; 76(1): 281S-5S.

20 Brand-Miller J, Hayne S, Petocz P, Colagiuri S. Low-glycemic index diets in the management of diabetes: a meta-analysis of randomized controlled trails. Diabetes Care 2003; 26(8): 2261-7.

21 Sloth B, Krog-Mikkelsen I, Flint A, Tetens I, Bjorck I, Vinoy S, et al. No difference in body weight decrease between a low-glycemic-index and a high-glycemic-index diet but reduced LDL cholesterol after 10-wk ad libitum intake of the low-glycemic-index diet. American Journal of Clinical Nutrition 2004; 80(2): 337-47.

22 Ebbeling CB, Leidig MM, Sinclair KB, Seger-Shippee LG, Feldman HA, Ludwig DS. Effects of an ad libitum lowglycemic load diet on cardiovascular disease risk factors in obese young adults. American Journal of Clinical Nutrition 2005; 81(5): 976-82.

23 Frost G, Leeds AA, Dore CJ, Madeiros S, Brading S, Dornhorst A. Glycaemic index as a determinant of serum HDL-cholesterol concentration. Lancet 1999; 353(9158): 1045-8.

24 Liu S, Willett WC, Stampfer MJ, Hu FB, Franz M, Sampson L, et al. A prospective study of dietary glycemic load, carbohydrate intake, and risk of coronary heart disease in US women. American Journal of Clinical Nutrition 2000; 71(6): 1455-61.

25 van Dam RM, Visscher AW, Feskens EJ, Verhoef P, Kromhout D. Dietary glycemic index in relation to metabolic risk factors and incidence of coronary heart disease: the Zutphen Elderly Study. European Journal of Clinical Nutrition 2000; 54(9): 726-31.

26 Ford ES, Liu S. Glycemic index and serum high-density lipoprotein cholesterol concentration among US adults. Archives of Internal Medicine 2001; 161(4): 572-6.

27 Ma Y, Olendzki B, Chiriboga D, Hebert JR, Li Y, Li W, et al. Association between dietary carbohydrates and body weight. American Journal of Epidemiology 2005; 161(4): 359-67.

28 Liese AD, Schulz M, Fang F, Wolever TM, D'Agostino RB Jr, Sparks KC, et al. Dietary glycemic index and glycemic load, carbohydrate and fiber intake, and measures of insulin sensitivity, secretion, and adiposity in the Insulin Resistance Atherosclerosis Study. Diabetes Care 2005; 28(12): $2832-8$.
29 Slyper A, Jurva J, Pleuss J, Hoffmann R, Gutterman D. Influence of glycemic load on HDL cholesterol in youth. American Journal of Clinical Nutrition 2005; 81(2): 376-9.

30 Pawlak DB, Kushner JA, Ludwig DS. Effects of dietary glycaemic index on adiposity, glucose homoeostasis, and plasma lipids in animals. Lancet 2004; 364(9436): 778-85.

31 Pereira MA, O'Reilly E, Augustsson K, Fraser GE, Goldbourt $\mathrm{U}$, Heitmann BL, et al. Dietary fiber and risk of coronary heart disease: a pooled analysis of cohort studies. Archives of Internal Medicine 2004; 164(4): 370-6.

32 Slavin JL. Dietary fiber and body weight. Nutrition 2005; 21(3): 411-8.

33 Bjorck I, Elmstahl HL. The glycaemic index: importance of dietary fibre and other food properties. Proceedings of the Nutrition Society 2003; 62(1): 201-6.

34 Finch S, Doyle W, Lowe C, Bates CJ, Prentice A, Smithers G, et al. National Diet and Nutrition Survey: People aged 65 years and over. Vol. 1. Report of the Diet and Nutrition Survey. London: The Stationery Office, 1998.

35 Garrow JS, Webster J. Quetelet's index $\left(\mathrm{W} / \mathrm{H}^{2}\right)$ as a measure of fatness. International Journal of Obesity 1985; 9(2): $147-53$.

36 Hughes JM, Smithers G, Gay C, Clarke PC, Smith P, Lowe C, et al. The British National Diet and Nutrition Survey of people aged 65 years or over: protocol and feasibility study. Proceedings of the Nutrition Society 1995; 54(3): 631-43.

37 MAFF Nutrient Databank. Nutrition and Food Science 1993; 2: $16-9$.

38 Foster-Powell K, Holt SH, Brand-Miller JC. International table of glycemic index and glycemic load values: 2002. American Journal of Clinical Nutrition 2002; 76(1): 5-56.

39 Brand-Miller J. Glycemic Index [online], 13 December 2005. Available at www.glycemicindex.com Accessed January 2006.

40 Henry CJ, Lightowler HJ, Strik CM, Renton H, Hails S. Glycaemic index and glycaemic load values of commercially available products in the UK. British Journal of Nutrition 2005; 94(6): 922-30.

41 Flint A, Moller BK, Raben A, Pedersen D, Tetens I, Holst JJ, et al. The use of glycaemic index tables to predict glycaemic index of composite breakfast meals. British Journal of Nutrition 2004; 91(6): 979-89.

42 Wolever TM, Jenkins DJ. The use of the glycemic index in predicting the blood glucose response to mixed meals. American Journal of Clinical Nutrition 1986; 43(1): $167-72$.

43 Schofield WN. Predicting basal metabolic rate, new standards and review of previous work. Human Nutrition. Clinical Nutrition 1985; 39(Suppl. 1): 5-41.

44 Goldberg GR, Black AE, Jebb SA, Cole TJ, Murgatroyd PR, Coward WA, et al. Critical evaluation of energy intake data using fundamental principles of energy physiology: 1 . Derivation of cut-off limits to identify under-recording. European Journal of Clinical Nutrition 1991; 45(12): 569-81.

45 Brown CD, Higgins M, Donato KA, Rohde FC, Garrison R, Obarzanek E, et al. Body mass index and the prevalence of hypertension and dyslipidemia. Obesity Research 2000; 8(9): 605-19.

46 Rasmussen BM, Vessby B, Uusitupa M, Berglund L, Pedersen E, Riccardi G, et al. Effects of dietary saturated, monounsaturated, and $n-3$ fatty acids on blood pressure in healthy subjects. American Journal of Clinical Nutrition 2006; 83(2): 221-6.

47 Granfeldt Y, Bjorck I, Hagander B. On the importance of processing conditions, product thickness and egg addition for the glycaemic and hormonal responses to pasta: a comparison with bread made from 'pasta ingredients'. European Journal of Clinical Nutrition 1991; 45(10): 489-99. 
48 Roberts SB. Glycemic index and satiety. Nutrition in Clinical Care 2003; 6(1): 20-6.

49 Spieth LE, Harnish JD, Lenders CM, Raezer LB, Pereira MA, Hangen SJ, et al. A low-glycemic index diet in the treatment of pediatric obesity. Archives of Pediatrics \& Adolescent Medicine 2000; 154(9): 947-51.

50 Ebbeling CB, Leidig MM, Sinclair KB, Hangen JP, Ludwig DS. A reduced-glycemic load diet in the treatment of adolescent obesity. Archives of Pediatrics \& Adolescent Medicine 2003; 157(8): 773-9.

51 St Onge MP. Relationship between body composition changes and changes in physical function and metabolic risk factors in aging. Current Opinion in Clinical Nutrition and Metabolic Care 2005; 8(5): 523-8.

52 Wolever TM, Bentum-Williams A, Jenkins DJ. Physiological modulation of plasma free fatty acid concentrations by diet. Metabolic implications in nondiabetic subjects. Diabetes Care 1995; 18(7): 962-70.

53 Daly M. Sugars, insulin sensitivity, and the postprandial state. American Journal of Clinical Nutrition 2003; 78(4): $865 \mathrm{~S}-72 \mathrm{~S}$.

54 Abbott RD, Garrison RJ, Wilson PW, Epstein FH, Castelli WP, Feinleib M, et al. Joint distribution of lipoprotein cholesterol classes. The Framingham study. Arteriosclerosis 1983; 3(3): $260-72$.

55 Millar JS, Lichtenstein AH, Cuchel M, Dolnikowski GG, Hachey DL, Cohn JS, et al. Impact of age on the metabolism of VLDL, IDL, and LDL apolipoprotein B-100 in men. Journal of Lipid Research 1995; 36(6): 1155-67.

56 Mahley RW. Development of accelerated atherosclerosis. Concepts derived from cell biology and animal model studies. Archives of Pathology \& Laboratory Medicine 1983; 107(8): 393-9.
57 Pryer JA, Vrijheid M, Nichols R, Kiggins M, Elliott P. Who are the 'low energy reporters' in the dietary and nutritional survey of British adults? International Journal of Epidemiology 1997; 26(1): 146-54.

58 Cook A, Pryer J, Shetty P. The problem of accuracy in dietary surveys. Analysis of the over 65 UK National Diet and Nutrition Survey. Journal of Epidemiology and Community Health 2000; 54(8): 611-6.

59 Wolever TM. Aspects of some vitamins, minerals and enzymes in health and disease. In: Bourne GH, ed. The Glycaemic Index. Basel: Karger, 1990; 120-85.

60 MacMahon S, Peto R, Cutler J, Collins R, Sorlie P, Neaton $\mathrm{J}$, et al. Blood pressure, stroke, and coronary heart disease. Part 1, Prolonged differences in blood pressure: prospective observational studies corrected for the regression dilution bias. Lancet 1990; 335(8692): 765-74.

61 Jenkins DJ, Wolever TM, Taylor RH, Barker H, Fielden H, Baldwin JM, et al. Glycemic index of foods: a physiological basis for carbohydrate exchange. American Journal of Clinical Nutrition 1981; 34(3): 362-6.

62 Wolever TM, Bolognesi C. Prediction of glucose and insulin responses of normal subjects after consuming mixed meals varying in energy, protein, fat, carbohydrate and glycemic index. Journal of Nutrition 1996; 126(11): 2807-12.

63 Greiser KH, Kluttig A, Schumann B, Kors JA, Swenne CA, Kuss $\mathrm{O}$, et al. Cardiovascular disease, risk factors and heart rate variability in the elderly general population: design and objectives of the CARdiovascular disease, Living and Ageing in Halle (CARLA) Study. BMC Cardiovascular Disorders 2005; 5: 33 .

64 Allen JK. Genetics and cardiovascular disease. Nursing Clinics of North America 2000; 35(3): 653-62. 